\title{
The Impact of ICT on Labour Productivity - Europe vs. U.S.
}

\author{
Predrag Trpeski ${ }^{1}$, Borce Trenovski ${ }^{1}$, Gunter Merdzan ${ }^{1,}$, and Kristijan Kozeski ${ }^{1}$ \\ ${ }^{1}$ Ss. Cyril and Methodius University in Skopje, Faculty of Economics - Skopje, Blvd. Goce Delchev \\ 9V, 1000 Skopje, Republic of North Macedonia
}

\begin{abstract}
Research background: The European economy has been experiencing declining productivity growth rates since the 1970s despite high investments in information and communication technologies (ICT). Investments in ICT are considered a key driver of productivity growth that serves as a basis for further improvements in living standards. However, despite the emergence of new technologies and industries, especially after 1995, European productivity growth has slowed and lagged behind the United States. The critical question is why?

Purpose of the article: This article aims to examine the effects of ICT on the European labour market in the period when machines and systems such as artificial intelligence, new information technologies, the Internet of things, and other technologies are becoming increasingly interconnected and intertwined. Additionally, the article examines the key reasons why European productivity lags behind the U.S. and explains them.

Methods: The panel regression method analyzes the productivity lag of selected European developed countries and emerging markets in 2007-2019. The article additionally makes a qualitative analysis of the benefits of new technologies on productivity in Europe compared to the U.S.

Findings \& Value added: The results of the econometric analysis applied in this article confirm the positive but insignificant impact of ICT investments on the labour productivity of the case of European developed countries in the post-Great Recession period. Thus, the article fills the gap in the research literature regarding the relationship between ICT investments and the labour productivity of selected European countries.
\end{abstract}

Keywords: ICT; labour productivity; multifactor productivity; Europe, the U.S.

JEL Classification: $J 24$; O30; O52

\footnotetext{
*Corresponding author: guntermercan10@gmail.com; gjunter.merdzan@eccf.ukim.edu.mk
} 


\section{Introduction}

Productivity growth lays the groundwork for improving living standards. This is because a country's ability to improve its standard of living over time depends almost entirely on its ability to increase per capita output. Unfortunately, most countries do not have natural resources like oil or gas reserves and cannot get wealthy. So, the only way for such societies to become more prosperous is to improve their living standards by producing more goods and services with the same number of people. Thus, the question that drives productivity growth can be answered: (1) Part of productivity comes from using more resources; (2) But most of it comes from improving our ability to create more output with given inputs. So, most of the productivity growth is realized through technological innovations and production techniques.

Investments in information and communication technologies (ICT) are considered a key driver of productivity growth. However, of course, the impacts of ICT on economic growth in developing countries and emerging markets differ from those in developed countries. According to Niebel (2018), there are several valid reasons for this: (1) Developing countries and emerging markets may not have the capacity to absorb adequate levels of human capital or other complementary factors such as research and development costs and therefore receive less investment in ICT compared to developed countries; (2) On the other hand, ICT can enable developing countries and emerging markets to bypass traditional methods of increasing productivity (Steinmueller, 2001) and find alternative and faster ways to reach the goal.

This article examines the problem aims to examine the problem of slowing productivity growth after 1995, especially after the Great Recession of 2007-2009, and compares the United States and selected European developed economies and emerging markets. Since the mid-1990s, productivity growth patterns have varied between the U.S. and Europe. Slower labour productivity in Europe is changing the long-term path to convergence. Van Ark, O'Mahoney, \& Timmer (2008) and European Commission (2011), distinguish three essential periods in terms of productivity growth between the U.S. and Europe: (1) The first period was 1950-1973, in which productivity growth in the EU follows a traditional pattern, maintained by strong investment and institutional support. This process lasted until the 1970s; (2) The second period was 1973-1995 when productivity growth in Europe and the U.S. began to slow. However, average annual labour productivity growth in the EU-15 was still twice as fast in the U.S., and the productivity gap was very narrow by 1995 ; (3) From 1995 onwards, U.S. productivity growth accelerated in the third period, while productivity growth in Europe fell. By 2004, GDP per hour worked in the EU was about ten percentage points below the U.S. level.

Numerous studies suggest that accelerating productivity in the U.S. reflects a fundamental acceleration technology. Therefore, in this article, we ask why there is a slowdown in productivity growth in Europe? Additionally, we add to the previous division and analyze the fourth period, i.e., after the Global Financial Crisis until 2019, as a period of greater deterioration.

The article is structured as follows: The introductory part is followed by a section where we elaborate on the possible reasons why European productivity lags behind that of the United States and explain them. The third section deals with the data and methodology of the analysis. The following is the section with the results and the discussion of the findings. Finally, we conclude based on the qualitative comparative analysis and econometric analysis conducted in the article. 


\section{The Reasons for the backwardness of Productivity of Selected European Countries compared to the U.S.}

As can be concluded from above, despite the advent of artificial intelligence, robotics, and the Internet of Things, European productivity growth -expressed either as labour productivity or as an MFP that primarily consists of innovation and technological benefits- has slowed and continues to lag behind that of the United States. Since the financial crisis in 2008, the labour productivity of EU member states has grown by only $0,7 \%$ annually. At this rate, doubling per capita income in Europe would take a century. Moreover, while Europe narrowed the productivity gap with the United States before 1995, the gap has only widened since then. For Europe to successfully tackle the problems mentioned above, such as demographic challenges, exceptionally rapid population aging, and to compete in global markets, it is crucial to return to the pre-1995 trend and move closer to the U.S. level of productivity. Moreover, to achieve this requires the ubiquitous use -not just for productionof information and communication technologies across Europe. However, here we somehow see the "Solow paradox" come to light, and despite the high investment in ICT by European economies, productivity has not been able to move forward since 1995 .

Scientific evidence strongly suggests that increased investment in ICT, especially in the Fourth Industrial Revolution technologies (AI, IoT, robotics) and the transformational change that ICT bring to organizations, is a critical component in determining Europe's lagging productivity (Atkinson, 2018). ICT is a general-purpose technology that is changing production and distribution systems, with far-reaching effects throughout the economy.

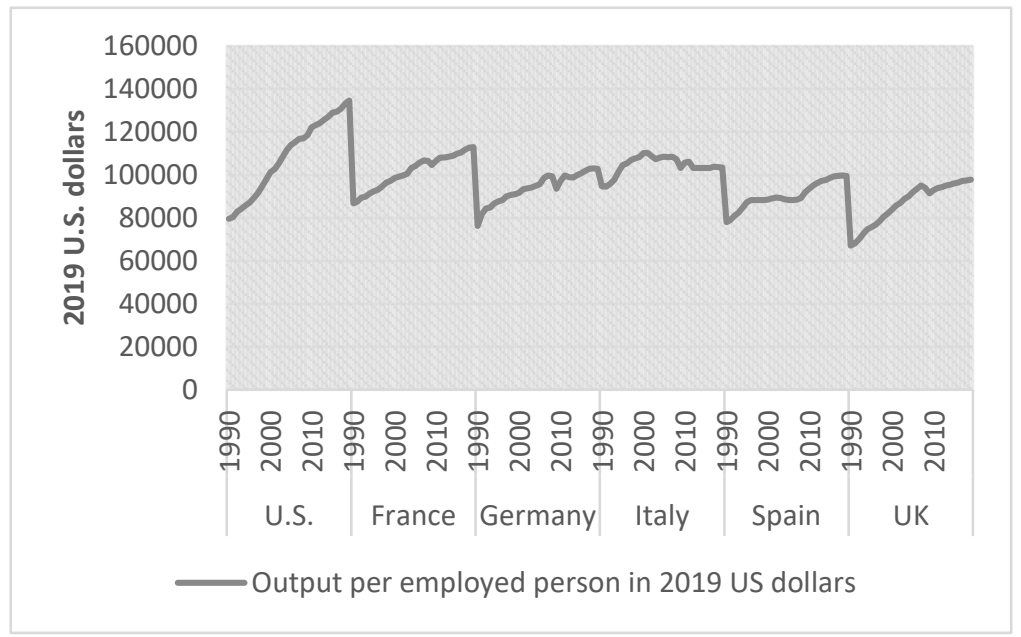

Chart 1. Comparison of the level of output per employed person between the U.S. and selected European countries

Source: The Conference Board Total Economy Database

Compared to the United States, Europe has far smaller productivity gains than ICT (Chart 1). Although the contribution of ICT varies between European countries -only two Scandinavian countries (Denmark and Sweden) received more ICT compared to the United States- other European countries managed to derive more minor benefits (Atkinson, 2018). These variations between countries, together with variations at the industry and firm level, clearly provide evidence that those countries, industries, and firms that invest in and use more ICT have significant benefits. 


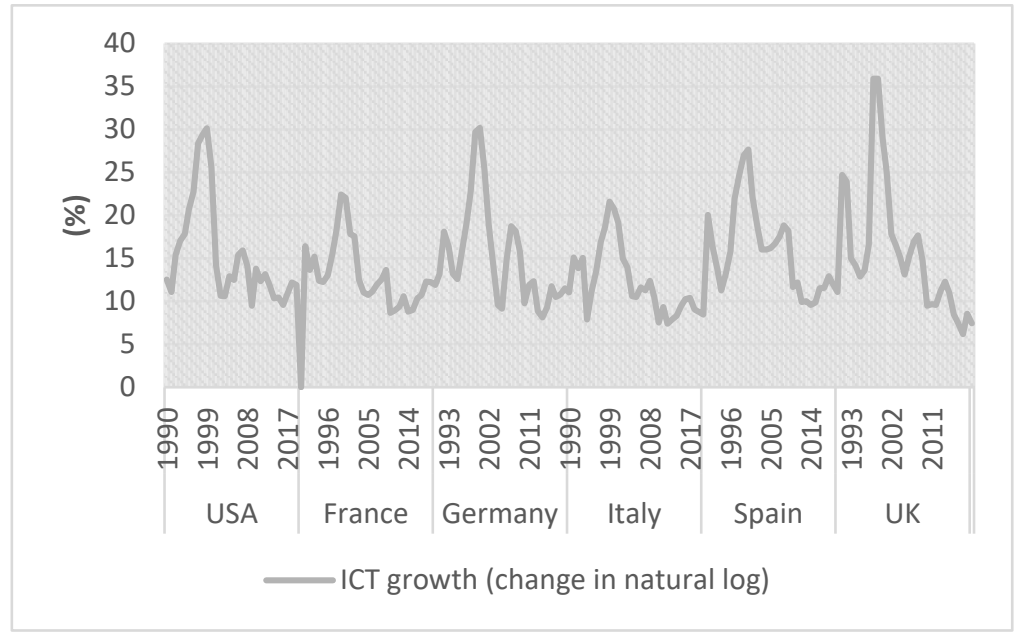

Chart 2. Comparison of the ICT investments growth between the U.S. and selected European countries

Source: The Conference Board Total Economy Database

However, the more limited productivity gains in Europe from ICT were initially a mystery, as in many ways, Europe seemed to be investing in new technologies. The first reason would be lower levels of capital investment in ICT. Since the 1990s, European countries have lagged far behind the United States regarding ICT investment levels, both as percentage of total fixed capital investment and GDP (Chart 2). Moreover, this applies not only to the ICT production sector itself. All sectors that use ICT, primarily the service sector, have invested less in ICT than in the United States. As a result, the productivity of European private sector services increased by less than half that in the United States between 2006 and 2016, as the positive effects of ICT production did not spread to general use.

According to Atkinson (2018), there are four main reasons for Europe's failure to invest in and benefit from ICT:

1. Regulation of the product, labour, and land markets limits possible business models, increases ICT investment costs, and slow down-market forces that may force firms to adopt more effective practices. For example, privacy regulations are reducing the effectiveness of online advertising, which is why, as part of GDP, digital advertising spending was three times higher in the U.S. than in Europe 2017.

2. Consumption taxes on ICT products in the EU are higher, which reduces the adoption of ICT by consumers and businesses. Corporate tax policies may also play a role, as depreciation rates for ICT capital investments are generally less generous than in the United States.

3. European businesses have difficulty accessing larger markets that provide larger economies of scale. Despite the European Commission's initiative for single digital market, the markets are still fragmented. This fragmentation limits the potential size of markets, making it harder for companies to achieve economies of scale from ICT investments. This is crucial because ICT enables companies to increase sales by capturing larger markets. In addition, the large share of small firms in Europe complicates the process of overcoming the high fixed costs of many ICT investments, limiting ICT use and productivity in small firms. Furthermore, by favouring small companies over larger ones, the EU tax, spending, and EU regulatory policies artificially keep company sizes smaller, leading to reduced ICT investment and productivity. 
4. Another reason would be management styles. Utilizing the full potential of ICT investments requires an organizational redesign, as mentioned earlier, and it proves that U.S. firms are better than EU firms in implementing techniques that can facilitate such a transformation.

Nevertheless, we can say that although productivity growth in Europe and the United States (to a lesser extent than Europe) despite significant investments in ICT, there is still reason for some optimism in future. The Fourth Industrial Revolution, and the Fifth Industrial Revolution, which in several highly developed countries are being talked about and the new technologies they bring (robotics, AI, autonomous systems, IoT, etc.), although it is still too early to be reflected in today productivity statistics. However, their effects in the next 5 to 10 years will be noticeable. Also, exploiting the full potential of these ICT investments and their reflection in productivity statistics eliminates irrational views such as technology will lead to higher unemployment (Trenovski \& Merdzan, 2020). In addition, the benefits of investing in ICT will be fully seen when focusing on increasing productivity in all sectors where ICT is used, as only ICT-producing sectors are unlikely to provide significant productivity growth in the economy without the adoption of ICT in other sectors. Of course, to fully utilize the benefits of ICT investments, tax and trade policies and other conditions should be included (Merdzan, Domazet, Sucubasi, \& Imeri, 2020).

\section{Literature Review}

The early studies of the impact of ICT on productivity remained largely unconvincing. The well-known "Paradox of Solow", in which he says that "computers are visible everywhere except in productivity statistics", sums up the situation in the early 1990s. The lack of correlation between ICT investments and productivity increase was primarily due to incorrect measurement of the prices and the quality of ICT capital. Significant improvements in the measurement of ICT capital (OECD, 2009) paved the way for a new wave of analysis of the effects of ICT capital on labour productivity. Whereas the work performed by the OECD on the international harmonization of ICT prices (Colecchia \& Schreyer, 2002), enabled the control of the differences in the methodologies between the countries. Most macroeconomic and industrial studies are based on the growth accounting framework, where it was supposed that the contribution of every input in the production is proportional to appropriate participation in the total input costs. Thus, the increase in production over input contributions is attributed to the growth of multifactorial productivity, i.e., a technological advance that is not embodies in the production inputs.

Empirical work on the macro level about the connection between ICT and economic growth is based on accounting growth and econometric studies. Several studies of economic growth accounting reveal the economically significant contributions of ICT capital to economic growth since the 1990s in developed countries. Studies by Oliner \& Sichel (2000), and Jorgenson \& Stiroh (2000), focus on the effects of ICT on productivity in the United States as European statistics have shown that the ICT industry in Europe is lagging to the United States.

Jorgenson \& Stiroh (2000), applied the limit of the production capacities of Jorgenson (1967) to explain the increase of the growth of productivity in the U.S. after 1995. They discovered that the computer hardware had a more significant role as a source of economic growth and the average labour productivity has grown much faster between 1995 and 1999 due to capital deepening as a direct consequence of decreased ICT prices and rising MFP. Oliner \& Sichel (2000), had similar results based on the model similar to Solow's accounting growth. They discovered that the ICT contribution had increased between the period from 1974-1996 and 1996-1999 and that the MFP growth was also increased by $40 \%$ in the period from 1996-1999. 
Colecchia \& Schreyer (2002), explained the approach followed by Jorgenson \& Stiroh (2000), and Oliner \& Sichel (2000), on nine OECD countries until 2000. They have discovered that ICT contributed between 0,2 and 0,5 percentage points annually to the economic growth depending on the country in the last two decades.

During the second half of the ' 90 s, this contribution increased to 0,3 and $0,9 \%$ annually. The contribution of ICT investment to economic growth is highest in the United States, followed by Australia, Finland, and Canada. Germany, Italy, France, and Japan had the lowest ICT contributions to the economic growth of the nine countries surveyed. Oulton (2002), applies a modified growth accounting approach to the UK, using U.S. producer price indexes adjusted for exchange rates to refine the value of ICT investments. He found that ICT's contribution to the GDP growth increased from $13,5 \%$ in $1979-89$ to $20,7 \%$ in 1989 98. In addition, ICT contributed $55 \%$ of the capital deepening during $1989-98$ and $90 \%$ for 1994-98.

In their paper, Van ark, Inklaar, \& McGuckin (2003), explained the main reasons for lower productivity growth in the 90 s in Europe compared to that of the United States. The findings illustrated that productivity in the U.S. is improving faster than in the EU, where a larger share of employment is in the ICT manufacturing sector, and faster productivity growth is in sectors that have an intensive use of ICT services. Inklaar, Timmer, \& O’Mahony (2005), compares ICT contributions to U.S. industry and several developed EU countries (France, Germany, the Netherlands, and the United Kingdom), showing more significant contributions to the U.S. than the EU from 1979 to 2000. By publishing of the database EU KLEMS (O'Mahony \& Timmer, 2009), cross-country studies such as Inklaar, Timmer, \& Van Ark (2008), Van Ark, O’Mahoney, \& Timmer (2008), etc., showing significant sectorial and cross-country heterogeneity to the contribution of ICT to labour productivity growth in developed countries appeared.

Several other macro-level econometric studies of ICT and productivity in developed countries have also been conducted. Stiroh (2002), surprisingly finds negative elasticity of ICT capital relative to output in its pooled regressions using the least squares (OLS) method and instrumental variable regressions (IV-regressions) based on U.S. manufacturing industry data for the period 1984-1999. With an updated data set and a more detailed breakdown of the industry, Stiroh (2005), reports on positive ICT capital ratios in the regressions of the production function. Based on dynamic panel data estimates, Dimelis \& Papaioannou (2011) show that investment in ICT capital has a significant effect on the production growth for both the United Kingdom and the U.S.. Dahl, Kongsted, \& Sørensen (2011), confirm these findings for eight European countries using EU KLEMS data (O'Mahony \& Timmer, 2009).

However, the Financial Crisis of 2008 painted a somewhat different picture in advanced economies, with negative GDP growth rates in both the U.S. and the European Union: EU15 GDP growth decreased to $0,3 \%$, in 2008 and then plummeted at $-4,3 \%$ in 2009 . However, in the United States, the adjustment to the crisis occurred mainly in the labour market and resulted in a dramatic increase in unemployment, while in Europe, job losses were smaller, and the adjustment occurred through a reduction in labour productivity. However, the quality of labour and investment in ICT contributes the growth in developed countries (Van Ark, 2010).

The potential to influence the economic growth of ICT, in the long run, is at the hearth of Oulton's (2010), work. The two-sector model of accounting growth shows that the main impetus for growth comes precisely from the use of ICT and not from the production of ICT.

Even a country with zero production of ICT can benefit by improving the trade conditions. In the long run, the decrease in the relative price of ICT products increases the growth of GDP and consumption by causing a faster accumulation of ICT capital. The author quantifies this effect on the long-term rate on the sample from 15 European and four nonEuropean countries using the database of EU KLEMS. The intensity of the labour production 
of ICT (participation of ICT in the profit) is smaller in many European countries than in the U.S. or Sweden. However, the contribution to long-term labour productivity growth resulting from current ICT intensity levels is significant: about half a percent on average per year in the countries surveyed. In the end, the ICT revolution may be spread wider so that the ICT intensity may reach at least the same level that is currently in U.S. or Sweden, which will give additional $0,2 \%$ points annually of the long-term growth. These discoveries suggest that the policies should help remove the current barriers to implementation and use.

\section{Data and Methodology}

In order to analyze the impact of ICT on labour productivity, this article uses the panel regression method. Data were collected for five European developed countries (France, Germany, Italy, Spain, and the United Kingdom) and three Central and Eastern European emerging markets (Hungary, Poland, and Slovakia). We have included these countries in our analysis as a positive exception to the trend of slowing productivity growth in developed economies, where we will see the significant impact of ICT on productivity in the period after the Great Recession. As explained in detail above, after 1995, the trend of labour productivity growth in the United States began to accelerate, while in Europe, it slowed down, and after the Great Recession, the picture is even worse. Because of that, we decided that the analysis period should be 2007-2019, to focus more on the period after the Global Financial Crisis until 2019 when productivity growth slowed further despite the still high ICT investments - data taken from the Conference Board Total Economy Database. The dependent variable, labour productivity, is measured as output per hour worked growth (annual change in \%), and the explanatory variables used in the model are ICT growth (annual change in \%) and multifactor productivity growth (annual change in \%). The data on the ICT growth is obtained by differentiating from the first order the natural logarithms of the absolute values of the investments. Thus, all data are presented as annual growth rates.

As we mentioned above, to analyze the data, we employ the panel regression method. Econometrically, the general model we use for estimation when using panel data can be described as (Brooks, 2014):

$$
\gamma_{\mathrm{it}}=\alpha+\beta \mathrm{x}_{\mathrm{it}}+\mathrm{u}_{\mathrm{it}}
$$

where $\gamma_{\mathrm{it}}$ is a dependent variable, $\alpha$ is the intercept term, $\beta$ is a $\mathrm{k} \times 1$ vector of the parameters of the explanatory variables to be estimated, and $x_{i t}$ is a $1 \times \mathrm{k}$ vector of observations of the explanatory variables, $t=1, \ldots, T ; i=1, \ldots, N$.

To analyze the panel data, we employ a fixed-effects model. The simplest types of fixedeffect models allow the intercept in the regression model to differ between the crossmembers, but not over time, while all estimated slope coefficients are fixed both crosssectionally and temporally.

The fixed-effects model can be estimated using the following equation (Brooks, 2014):

$$
\gamma_{\text {it }}=\alpha+\beta x_{i t}+\mu_{i t}+v_{i t}
$$

where the error member $u_{i t}$, decomposes into an individual specific effect, $\mu_{\mathrm{i}}$, and the "remainder disturbance", $v_{i t}$, which varies with time and terms (including everything that remains unexplained for $\gamma_{i t}$ ). Thus, we can count on $\mu_{i}$ as covering all variables which affect $\gamma_{\text {it }}$ cross over, but do not differ over time. 


\section{Results and Discussion}

This section presents the results of the impact of ICT on labour productivity on the analyzed groups of countries in the period 2007-2019. We first present the results for the selected European developed countries and then for the selected Central and Eastern European emerging markets. First, before presenting the results of conducted empirical analysis, it is considered necessary to examine the integrative characteristics of the panel data, which implies the determination of stationarity of the variables. For this purpose, the LLC (Levin, Lin, and $\mathrm{Chu}$ ) is used in this article. Based on the results obtained from the conducted LLC test, it can be concluded that all of the variables are stationary at the level of $1 \%$ significance.

Table 1. Results for integrative characteristics of the variables

\begin{tabular}{|c|c|c|}
\hline \multicolumn{3}{|c|}{ Selected European Developed Economies } \\
\hline Variable & Statistics (LLC-test) & p-value of the statistics (LLC-test) \\
\hline ICT growth & $-6,35986$ & 0,0000 \\
\hline Output per hour worked growth & $-5,41818$ & 0,0000 \\
\hline MFP growth & $-4,46757$ & 0,0000 \\
\hline \multicolumn{2}{|c|}{ Selected European Emerging Markets } \\
\hline Variable & Statistics (LLC-test) & p-value of the statistics (LLC-test) \\
\hline ICT growth & $-4,04024$ & 0,0000 \\
\hline Output per hour worked growth & $-7,58897$ & 0,0000 \\
\hline MFP growth & $-4,70453$ & 0,0000 \\
\hline
\end{tabular}

Source: Authors' calculations

Then, we evaluate the two models, the first with the selected European developed economies and the other with the selected European emerging markets. Next, we perform the Hausman test to determine which panel regression techniques are preferable to apply in each of the two models. As a result, the p-values of the Chi-square statistics for the two models have a lower value of 0,1 , which means that we can reject the null hypothesis in each case and find out that fixed effects in each of the two models is recommended. The next step is to estimate the models, i.e., to determine the coefficients of the independent variables by imposing fixed effects on the cross-members in the model. Firstly, we go with the European developed economies sample. The following equation estimates it:

$$
\begin{aligned}
& \text { productivity }_{\text {per_hour }} \text { 2007-2019 } \\
& =\alpha+\beta_{1} \Delta \operatorname{lnICT}_{2007-2019}+\beta_{2} \Delta M F P_{2007-2019}+\mu \\
& +v_{2007-2019}
\end{aligned}
$$

Table 2. Results for the estimated coefficients of the variables used in model for selected European developed economies

\begin{tabular}{|c|c|c|c|}
\hline Explanatory variables & Coefficient & t-statistics & p-value \\
\hline ICT growth & 0,016409 & 0,671427 & 0,5046 \\
\hline MFP growth & $0,689060^{* * *}$ & 16,77186 & 0,0000 \\
\hline A & 0,617789 & 2,277176 & 0,0265 \\
\hline R $^{2}$ & 0,628795 & \multicolumn{1}{|}{} \\
\cline { 1 - 2 } F-statistics & $50,43153^{* * *}$ & \multicolumn{1}{|}{} \\
\cline { 1 - 2 } p-value (F-stat) & 0,000000 & \multicolumn{1}{|l}{} \\
\cline { 1 - 2 } &
\end{tabular}

Note: ${ }^{* * * * * *},{ }^{*}$ denote significance at the $1 \%, 5 \%$, and $10 \%$ levels, respectively; Source: Authors' calculations. 
Table 3. Results for the estimated coefficients of the variables used in model for selected European emerging markets

\begin{tabular}{|c|c|c|c|}
\hline Explanatory variables & Coefficient & t-statistics & p-value \\
\hline ICT growth & $0,044565^{* * *}$ & 3,044246 & 0,0045 \\
\hline MFP growth & $0,871816^{* * *}$ & 15,08513 & 0,0000 \\
\hline A & 1,231932 & 5,483165 & 0,0000 \\
\hline $\mathbf{R}^{2}$ & 0,901911 & & \\
\hline F-statistics & $78,15640^{* * *}$ & & \\
\hline p-value (F-stat) & 0,000000 & & \\
\hline
\end{tabular}

Note: ${ }^{* * *},{ }^{* *},{ }^{*}$ denote significance at the $1 \%, 5 \%$, and $10 \%$ levels, respectively; Source: Authors' calculations.

The estimate results indicate an appropriate level of conformity of the models. The coefficients of determination $\mathrm{R}^{2}$ are high, which shows that the variations in the models are explained by the variables included. Furthermore, the p-values of the F-statistics in both models are $0 \%$, i.e., they are less than $5 \%$, which means that the hypothesis that the explanatory variables together have a significant impact on the movements of the dependent variable can be accepted in each of the cases. Furthermore, the implementation of the JarqueBera test also confirms the assumption of the normal distribution of residuals in both cases. In the first model with developed countries, the p-value of the test statistics is $59,19 \%$, and in the model with emerging markets $78,75 \%$, i.e., they have a higher value of $5 \%$, in which case we can not reject the null hypothesis that residuals follow a normal distribution. Based on the results obtained from the conducted diagnostic tests, it can be concluded that the models are well adapted, and the results obtained from the coefficients are objective and reflect the proper relationship between the analyzed variables.

Regarding the estimated coefficients, we can claim that our assumptions are met. As pointed out in several places above, labour productivity growth in European developed countries slowed down after the Great Recession despite high ICT invetsments. The results clearly showed that ICT has a positive but insignificant effect on labour productivity growth at the developed countries in the analyzed period. While, a positive exception to this trend are several emerging markets Central and Eastern Europe. In our model we analyzed Hungary, Poland and Slovakia. The results clearly show that in the example of these countries, the ICT investments growth positively and significantly affects the growth of labour productivity.

\section{Conclusion}

This article explores the problem of the slowdown in labour productivity growth after 1995, especially after the Great Recession in the United States and selected European developed countries and emerging markets. The first part discusses the trend that has gripped the global world in recent decades, including developed countries, i.e., the slowdown in productivity growth despite high investments in ICT. After introducing technologies such as electricity, internal combustion engines and their implementation and adaptation in production systems in the mid-20 $0^{\text {th }}$ century, especially in the $1940 \mathrm{~s}, 1950 \mathrm{~s}$, and $1960 \mathrm{~s}$, productivity growth was remarkably rapid. However, since 1973, productivity growth has slowed. In 1987, Nobel laureate Robert Solow famously noted that the slowdown in productivity growth almost coincided with the early days of the computer revolution. Computers were still a tiny part of the economy, but such technologies as information technology to show overall effect are needed in organizations where they applied to take additional complementary investments, and it took time. Recent research based on detailed data on IT technologies and productivity suggests a significant and strong correlation between them. Companies that used IT or other 
technologies and supplemented them with complementary innovations in the following years enjoyed high productivity growth. This is still happening today, especially in the period after the Great Recession. Despite the rapid growth of new technologies from the Fourth Industrial Revolution, they are not reflected in productivity statistics. We can conclude that the benefits of these technologies on the overall economy and labour productivity will be reflected in the statistics once the necessary additional complementary investments are made in organizations and the economy, which will take time.

Section 2 shows the possible reasons why European productivity lags behind that of the United States. We conclude that there are several reasons for Europe to lag behind the U.S. in productivity growth: regulation, consumption taxes on ICT products, the difficulties faced by European businesses in accessing foreign markets, market fragmentation, the large share of small companies across Europe, European business management styles and others. In the third part, we briefly overview the literature on labour productivity and ICT investments in the U.S. and European countries at the macro and micro levels and share the experiences. The following parts present the data, methodology used to confirm the claims expressed throughout the article, and estimation results. First, it analyzes five developed European countries (France, Germany, Italy, Spain and United Kingdom) and 3 European emerging markets from Central and Eastern Europe (Hungary, Poland, and Slovakia) for the period 2007-2019. The results show a positive but insignificant impact of ICT investments on labour productivity in developed countries in that period, which confirms the theses listed above. In comparison, a positive exception is several of the emerging markets in Central and Eastern Europe that show a positive and significant impact of ICT investments on labour productivity in the analyzed period. This can be explained by the additional benefits that ICT investments have, such as ICT related spillovers or network effects, as they reduce transaction costs when ICT is used by many companies, not just those that produce ICT.

\section{References}

1. Atkinson, R. D. (2018). How ICT Can Restore Lagging European Productivity Growth. Information Technology \& Innovation Foundation.

2. Brooks, C. (2014). Introductory Econometrics for Finance. Cambridge: Cambridge University Press.

3. Colecchia, A., \& Schreyer, P. (2002). ICT Investment and Economic Growth in the 1990s: Is the United States a Unique Case? A comparative Study of Nine OECD Countries. Review of Economic Dynamics, 5(2), 408-442.

4. Dahl, C., Kongsted, H., \& Sørensen, A. (2011). ICT and productivity Growth in the 1990s: Panel Data Evidence on Europe. Empirical Economics, 40(1), 141-164.

5. Dimelis, S., \& Papaioannou, S. (2011). ICT Growth Effects at the Industry Level: A Comparison between the US and the EU. Information Economics and Policy, 23(1), 3750.

6. European Commission. (2011). Assessment Paper 1 The Impact of ICT on Productivity and Growth September 2011 Differences in Productivity Growth between Europe and the US.

7. Inklaar, R., Timmer, M. P., \& O'Mahony, M. (2005). ICT and Europe's Productivity Performance: Industry-Level Growth Account Comparisons with the United States. Review of Income and Wealth, 51(4), 505-536.

8. Inklaar, R., Timmer, M. P., \& Van Ark, B. (2008). Market Services Productivity Across Europe and the US. Economic Policy, 23(53), 139-194. 
9. Jorgenson, D. W., \& Stiroh, K. J. (2000). Raising the Speed Limit: U.S. Economic Growth in the Information Age. Brookings Papers on Economic Activity, 31(1), 125 236.

10. Merdzan, G., Domazet, E., Sucubasi, B., \& Imeri, B. (2020). Effects of Automation on Labour Markets in the Emerging Countries. Proceedings of International Conference of Applied Sciences, Engineering and Mathematics (pp. 37-50). Skopje: International Balkan University.

11. Niebel, T. (2018). ICT and Economic Growth - Comparing Developing, Emerging and Developed Countries. World development, 104, 197-211.

12. OECD. (2009). Measuring Capital: OECD Manual 2009. OECD PUblishing.

13. Oliner, S. D., \& Sichel, D. E. (2000). The Resurgance of Growth in the Late 1990s: Is Information Technology the Story? Journal of Economic Perspectives, 14(4), 3-22.

14. O'Mahony, M., \& Timmer, M. P. (2009). Output, Input and Productivity Measures at the Industry Level: The EU KLEMS Database. The Economic Journal, 119(538), F374F403.

15. Oulton, N. (2002). ICT and Productivity Growth in the United Kingdom. Oxford Review of Economic Policy, 3(1), 363-379.

16. Oulton, N. (2010). Long Term Implications of the ICT Revolution for Europe: Applying the Lessons of Growth Theory and Growth Accounting. London: ICTNET 2nd Workshop on ICT, Intangibles and Innovation.

17. Steinmueller, W. E. (2001). ICTs and the Possibilities for Leapfrogging by Developing Countries. International Labour Review, 140(2), 193-210.

18. Stiroh, K. J. (2002). Information Technology and the U.S. Productivity Revival: What Do the Industry Data Say? American Economic Association, 92(5), 1559-1576.

19. Stiroh, K. J. (2005). Reassessing the Impact of IT in the Production Function: A MetaAnalysis and Sensitivity Tests. Annales d'Economic et de Statistique, 79(80), 529-561.

20. The Conference Board. (2019). The Conference Board Productivity Brief 2019.

21. Trenovski, B., \& Merdzan, G. (2020). Lessons Learned from the Fourth Industrial Revolution for the Global Economy. Knowledge International Journal, 43(1), 89-95.

22. Van Ark, B. (2010). Innovation and Competitiveness: Revaluating the Contribution to Growth. London: ICTNET 2nd Workshop on ICT, Intangibles and Innovation.

23. Van Ark, B., Inklaar, R., \& McGuckin, R. (2003). ICT and Productivity in Europe and the United States: Where Do the Differences Come From? CESifo Economic Studies, 49(3), 295-318.

24. Van Ark, B., O'Mahoney, M., \& Timmer, M. P. (2008). The Productivity Gap between Europe and the United States: Trends and Causes. Journal of Economic Perspectives, $22(1), 25-44$. 